\title{
The Role of Parents' Socio-Economic Conditions Against Mathematics Learning Outcomes of Madrasah Ibtidaiyah Students
}

\author{
Anna Fista Nugraheni, Avita Febri Hidayana \\ Masters Program, Islamic Elementary Teacher Education, \\ UIN Sunan Kalijaga, Yogyakarta, Indonesia \\ anafista1992@gmail.com
}

\begin{abstract}
One of the factors that influence children's development is the parents' socioeconomic status. Some students are revealed to have mathematics learning outcomes that have not yet reached the Minimum Mastery Criteria (Kriteria Ketuntasan Minimal or KKM). It might occur due to the economic conditions of parents. Therefore, the researchers desired to determine the effect of parents' socioeconomic status on the learning outcomes of students in the fifth-grade of the Madrasah Ibtidaiyah (Islamic Elementary School or MI) Islamiyah Karangpakel. The purpose of this study was to determine the effect of parents' socioeconomic status on student mathematics learning outcomes at Islamiyah Karangpakel. Questionnaires and documentation were used as data collection techniques. The study was conducted by quantitative methods with the type of expost de facto. The study population consisted of students in the fifth grade of MI Islamiyah Karangpakel, with a total of 20 students. The data analysis technique used Simple Linear Regression and was assisted by SPSS 16.0. Based on the calculation of the significance level of $5 \%$, it indicates that the influence of parents' socioeconomic status on student mathematics learning outcomes was in precentage $41,4 \%$, or has sufficient influence while other variables or factors influence the rest. Thus, it can be concluded that the influence of parents' social economic status influences students' mathematics learning outcomes.
\end{abstract}


Keywords: Socioeconomic status, Mathematics learning outcomes, Mastery learning

\section{INTRODUCTION}

According to Teguh (2015: 23-24), education is an effort to attract something in humans to provide programmed learning experiences in the form of formal, non-formal, and informal education in school, and out of school that lasts a lifetime aiming at optimizing individual abilities so that later on they can play the role of life appropriately. The purpose of education contains a description of the values that are good, noble, appropriate, correct, and beautiful for life, so educational goals have the function of guiding and something to be achieved in educational activities (Tirtarahardja; 1998: 37).

Learning is a process of the development of human life, and humans make individual qualitative changes so that their behavior develops by learning (Soemanto; 2012: 104). Meanwhile, according to Gagne in Ahmad Susanto (2014: 2), learning is interpreted as a process to get motivated in knowledge, skills, habits, and behavior. It is also in accordance with humanistic studies that the individual approach can support the increase in learning achievement (Adina \& Colomeischi, 2015: 745). So, learning is a process to develop the individu for some aspect, especially academic and personality.

One of the studies in learning objectives is a description of the behavior expected by students after the learning process takes place. Learning objectives are a way to determine learning outcomes (Avalos, 


\section{Mudarrisa: Jurnal Kajian Pendidikan Islam, Vol. 11, No. 2, 2019}

2011: 19). Learning outcomes can be assessed from the behavior or attitude of a student after learning activities (Anni; 2006: 5). It can be said that learning make someone has been change better than before.

Student learning was influenced by several factors that are classified into two, namely, internal and external factors. In this case, internal factors are factors that come from within the students, while external factors are factors that come from outside students, such as factors relating to the school environment, community environment, and family environment Oemar Hamalik (2009: 73). The family background has a big influence on children's learning success, the level of parental education, the size of the income, enough or lack of attention and guidance affect the achievement of children's learning outcomes. It supported by M. Dalyono (2010: 59) about factors in the state of the home also influence learning success, such as the size of the residence, whether or not the equipment or learning media also determines the success.

The economic situation of parents does not only affect the health of children but also affects the opportunities and quality of learning (Nana Syaodih, 2005: 48). Muhammad Thohir in Maftukhah (2016: 151) states that children with a low economic background get lack sufficient guidance and direction from their parents, because parents are focus more on how to meet their daily needs, while children those from upper-middle-class families get more guidance and good guidance from their parents.

At the initial observation, MI Islamiyah Karangpakel has a problem in the socioeconomic status of the parents of fifth-grade students. The 


\section{Mudarrisa: Jurnal Kajian Pendidikan Islam, Vol. 11, No. 2, 2019}

socioeconomic status of upper and middle-fifth-grade students comes from capable parents. However, children have low learning outcomes, even though they have been given tutoring. Meanwhile, students who from low economic parents, get lack guidance but obtain high learning outcomes.

Social status is the position of a person (body) in social relations or surroundings (Kamus Besar Bahasa Indonesia, 1998). Soerjono Soekanto (Abdulsyani, 2007: 92) said that social status is a person's place in general in a society that relates to other people in a social environment, prestige and rights, and obligations. Social status can be made possible to be a determinant in communication and position of individuals in society, from the upper class or lower class that determines their role in the community and neighborhood (Nasution, 1994: 73). The role is a result of social status, but the role is not an absolute thing because the role will function adequately when balanced with the personality, the attitude of each individual.

Social status, according to M. Arifin Noor (1997: 155), is the position of an individual in the group social life. While the economy is broadly defined as household rules or household management (Syafiq Humaisi, 2012: 67). Thus, it can be concluded that socioeconomic status is a condition that describes the position of a person or family in the community based on economic conditions that are visible from the human senses, and can determine the role of individuals in terms of the capable classification (upper class) or incapable (lower class) and the role is enhanced by personality that is owned by each individual. The size of the 


\section{Mudarrisa: Jurnal Kajian Pendidikan Islam, Vol. 11, No. 2, 2019}

house, residential area, work owned, source of income they have, total income, expenses, and savings and objects or items of high economic value is one indicator of a person's social status (Parson, 2008: 22).

Socio-economic indicators, according to Nasution (2010: 28), consist of a position, total income, level of education, religion, type and size of the house, and other matters relating to one's social status. While the grouping of economic conditions of parents relating to education includes poor economy, this situation will lead to limited learning tools, lack of funds provided by parents, and do not have an appropriate place to learn (Mudzakir \& Sutrisno, 1997: 164). While the economy is excessive (rich), different from the previous situation, this economic situation comes from the excess economy (rich). Children who come from this family may be lazy/reluctant to learn because they have too much fun. Maybe parents do not want to see their children study hard that this situation will hinder children's learning progress.

Furthermore, economic conditions are classified into several classes, namely: top-class upper class, in this class, the number is relatively small, including nobles, have a lot of inheritance, upper-middle-class, namely rich people, but nobles, business owners, doctors, and rich legal experts (Prabu, 2005: 42). While the classification of social status according to Coleman and Cressy in Sumardi (2004) in Ahmad Syahrozi states that there are two classifications of social status in society including, the upper socioeconomic status is a social class which is at the top consisting of people who are rich (capable), conglomerates and often 


\section{Mudarrisa: Jurnal Kajian Pendidikan Islam, Vol. 11, No. 2, 2019}

occupy the top positions of power. Whereas, Sitorus (2000) states that the upper socioeconomic status is the status or position of a person in the community that is obtained based on classification according to assets where assets owned above the average society in general and can fulfill their needs properly. Harvinghust and Taba in Wijaksana (1992) argue that people with upper social status are a group of families in a relatively small number of elites who live in elite urban areas.

Upper social status can be categorized or classified, Gunawan (2000) states that there are general characteristics of a family with social status for including a). Living in a modern luxury house with ownership status. b). family dependents of less than five people or earner is still productive, c). The head of the household works and usually occupies the professional level and above, and d). Having venture capital. It can be concluded that social status above is the fulfillment of individual needs that are seen with the senses (eyes), wealth above the average environment based on work, establishment, the fulfillment of needs, and ownership of valuable goods and can meet daily needs well.

Lower socioeconomic status is a person's ability to meet their needs below the average community in general in line with the theory of Sitoru (2000) said that lower socioeconomic status is a position in the community that is obtained based on classification according to wealth, where assets owned include less when compared to the average community in general and unable to meet their daily needs while according to Harvinghurst and Taba in Wijaksana (1992) states that the lower socioeconomic community 
is a community with a large enough number of families and also tends to always conflict with law enforcement agencies.

Lower social status also can be categorized or classified. Gunawan (2000) states that there are general characteristics of a family with social status such as: a) Living in a rented house or own house, but the conditions are still very simple, b) Family dependents of more than five people or breadwinners are no longer productive, c) The head of the household was unemployed or living on the assistance of relatives. It can be concluded that the lower socioeconomic status is a condition where individuals or groups cannot meet their daily needs, lack of shelter, clothing, and tend to take actions that violate the law and have the ability to fulfill needs below the average in general.

Learning outcomes are the abilities of students after the learning process; after the learning process, there will be an evaluation to determine student learning outcomes. Student learning outcomes have an essential role in learning because it aims to know the extent to which students understand and comprehend the material being taught. According to Hamalik (2004: 31), learning outcomes are patterns of behavior, values of revelation, attitudes, appreciation, application, and skills.

Learning outcomes are the results of interaction of not learning and not teaching according to Dimyati and Mudjiono (2013: 3), from it, the teacher acts as a teacher who ends with the process of evaluating learning outcomes, and learning outcomes are the culmination of the process undertaken to determine the extent of student comprehension 


\section{Mudarrisa: Jurnal Kajian Pendidikan Islam, Vol. 11, No. 2, 2019}

about a material. Sudjana (2009: 3) states that learning outcomes are essentially changes in behavior as a result of learning in a broader study covering the fields of cognitive, affective, and psychomotor.

Furthermore, Dimyati (2006: 3) states that learning outcomes are the result of interactions between learning and teaching. Learning outcomes are divided into two, namely the impact of teaching and the impact of accompaniment. The effect of teaching was the results that can be measured, for example, numbers in report cards or diplomas, while the impact of accompaniment is the application of knowledge and abilities in other fields or transfer of learning.

According to Sagala by Sulistyorini (2009: 7), some requirements must be possessed by students in order to succeed in learning, namely: the ability to think critically characterized by critical, logical, systematic, and objective thinking, to raise the interest and high motivation in subjects, develop talent of student interest in accordance with its potential, master the basic materials needed to continue next level of school, master one foreign language, especially English, achieve psychological stability (not experiencing adaptation and sexual problems): health physical, quiet environment, adequate economic life; and master learning techniques in school and outside of school.

Assessment of learning outcomes is a particular achievement of learning outcomes achieved by students, Suprijono states that learning outcomes are patterns of actions, values of understanding, attitudes, appreciation, and skills, referring to Gagne's thought (2013: 22), which are 


\section{Mudarrisa: Jurnal Kajian Pendidikan Islam, Vol. 11, No. 2, 2019}

including a). Verbal information, it was the capacity to express knowledge in the form of language, both oral and written, the ability to respond specifically to specific stimuli. This ability does not require symbol manipulation, problem-solving, or application of the rules; b). Intellectual skills, it is the ability to present concepts and symbols. Intellectual skills consist of the ability to categorize, analyze-synthesize facts-concepts, and develop scientific principles. Intellectual skills are the ability to carry out specific cognitive activities; c). A cognitive strategy is the ability to channel and direct cognitive activities. This ability includes the use of concepts and rules in solving problems, d). Motor skills, it is the ability to do a series of physical movements in relation and coordination to realize automatic physical movement, e). Attitude is the ability to accept or reject an object based on an assessment of the object. Attitudes in the form of the ability to internalize and externalize values. Attitude is the ability to become values as a standard of behavior.

According to Ahmad Susanto (2013: 5), two factors influence learning outcomes, namely: Internal factors (health, intelligence, talent, interests, motivation, and ways of learning), External factors (family, school, community, and the surrounding environment). Moreover, according to Syah, cited by Deni Kurniawan (2014: 22-23), factors that influence learning outcomes are classified into three kinds such as: internal factor, it consists of physical (physiological) and spiritual (psychological) elements of the learner. The physical element is the general condition of special conditions, especially the five senses. The 


\section{Mudarrisa: Jurnal Kajian Pendidikan Islam, Vol. 11, No. 2, 2019}

spiritual element is an element that comes from within human beings that influences the quality of the process and learning outcomes, which are dominated at the level of intelligence, attitude, talent, interests, and motivation. b) The external factor is a factor that originates from outside of the environment that includes the social and non-social environment. The social environment is family, teachers, school staff, the community, and friends. A non-social environment that is the state of the house, school, equipment, and nature c). Learning approach factors include the strategies and methods students use for learning.

In contrast to Ahmad Susanto, Slamet (2010: 3) mentions the factors that affect learning outcomes into two parts including internal factors, consisting of physical factors (health or not disabled), psychological factors (intelligence, attention, interests, talents, motives, maturity and readiness), and fatigue factors, external factors, consisting of family factors (the way parents educate, relationships between family members, home atmosphere, family economic situation, understanding of people age, and family background), community factors (student activities in the community, mass media, socializing friends, and community life forms), school factors (teaching methods, teacher-student relations, curriculum, student relations with students, school discipline, learning tools, school time, building conditions, learning methods and homework assignments).

The national education system, the formulation of educational goals, both curricular and instructional goals, uses the classification of learning outcomes from Benjamin Bloom that broadly divides them into 
three domains, namely cognitive, affective and psychomotor. The cognitive domain is concerned with intellectual learning outcomes consisting of six aspects, namely knowledge or memory, understanding, application, analysis, synthesis, and evaluation, and the first two aspects are called low-level cognitive, and the next four aspects include high-level cognitive. The affective domain refers to attitudes consisting of five aspects, namely acceptance, answer or reaction, judgment, organization, and internalization. The psychomotor domain is related to the learning outcomes of skills and ability to act. There are six aspects of the psychomotor domain, namely: reflex motion, basic motion skills, perceptual abilities, harmony or accuracy, complex skills movements, and expressive and interpretive movements.

From the above opinion, it can be concluded that learning factors and student learning outcomes are influenced by environmental conditions, families, individual students, economic factors and the influence of parental education, usually parents who have adequate education and good economics can deliver better student achievement results and satisfying. Besides, the psychology of children built from the family and the environment will affect learning outcomes. In addition to being supported by professional and technical teachers who have attitudes and communication between the teacher and students and student communication with other students, it also builds children's enthusiasm for learning outcomes. 
According to Almira (2014: 73), mathematics learning is a way to facilitate, encourage, and support students in learning. Learning mathematics at the elementary school level is one of the interesting studies since there are differences in characteristics, especially between the nature of students and the nature of mathematics. For that, we need a bridge that neutralizes these differences.

Elementary school children are experiencing development at the level of real to abstract thinking. Basic mathematical concepts, according to Didi Haryanto (2015: 3), include a. Instilling basic concept is learning a new mathematical concept when students have not yet learned the concept in this activity, media or teaching aids are expected to be used to help students' mindset abilities, $b$. Understanding the concept of steps is a further step of instilling the basic concepts. The aim is that students better understand a mathematical concept. c. Skills coaching is a continuation of the first and second steps. The aim is that students are more skilled in using various mathematical concepts. Further, Nursalam (2016: 6) states that mathematics is very important to be taught in SD/MI because mathematics is very useful in the daily lives of students and is needed as a basis for studying advanced mathematics and other subjects.

Furthermore, learning mathematics requires overall readiness given that mathematics is a systematically structured lesson, so media tools are needed to help speed up the learning process. In this case, parents as facilitators of student life can provide additional lessons with tiered math lessons that serve to introduce lessons and deepen mathematical material. 
In this case, an increase in student learning outcomes can be achieved when children get adequate facilities and additional expenses from parents (able). Learning mathematics also requires the readiness of students both from the students themselves and the environment (Indah, 2013: 116), such as classes, books, learning tools, ways of teachers' teaching, and others. It is because mathematics is a lesson that is arranged systematically and abstract. Therefore, if the process of learning mathematics is not supported by factors that influence, so there will be certain obstacles during the process of learning mathematics. The success or failure of the teaching and learning process of mathematics can be measured through student mathematics learning outcomes. If the results of student mathematics learning tend to be good, it can be said that the teaching and learning process has gone well. Conversely, if the results of student mathematics learning tend to be bad, of course, the teaching and learning process has experienced obstacles. This study focuses on the study of family economic status factors that affect mathematics learning outcomes of fifth-grade students of MI Islamiyah Karangpakel 2019/2020.

\section{METHODS}

This research used a quantitative approach with the expose de facto method in which to look back, the factors that cause something to happen. The sampling technique used was saturated sampling. This research was conducted at MI Islamiyah Karangpakel in February-March 2019. The independent variable in this study was the socioeconomic status of parents. While the dependent variable in this study was mathematics 


\section{Mudarrisa: Jurnal Kajian Pendidikan Islam, Vol. 11, No. 2, 2019}

learning outcomes. The population of this research was all fifth-grade students of MI Islamiyah Karangpakel. The questionnaires and documentation were utilized as data collection techniques.

The questionnaire in this study was a question to get data about the economic status of parents. The scale used was the Likert scale, a scale used to measure the attitudes and opinions of a person or group of people regarding social phenomena. Meanwhile, the documentation technique was applied to obtain the data in the form of the Midterm Exam (Ujian Tengah Semester or UTS) mathematics score of the fifth-grade students.

The prerequisites in the research instrument consisting of a validity test and reliability test. A validity test is used to measure the accuracy of the instruments used in research and test each item, and then the reliability test is performed to determine the accuracy and consistency of the instruments in the study. Before conducting data analysis, there was a data prerequisite test that is a normality test that aims to determine whether the data obtained is normal or not, then a linearity test is performed to determine the linear relationship between variables, and in the final stage, a simple regression test is utilized to reveal how much the influence of variables X and Y, by using the SPSS 16.0 program.

\section{DISCUSSION}

In this study, the prerequisite test data was conducted to determine the accuracy of the instruments used as well as knowing the condition of students in the class. The prerequisite tests included a normality test and a simple regression test of the questionnaire scores and the results of the 
mathematics UTS for the fifth grade of MI Islamiyah Karangpakel students. The results of the significance test of the fifth-grade students are shown in Table 1.

Table 1. UTS Test Data Significance value of the fifth grade of MI Islamiyah Karangpakel students

\begin{tabular}{lc}
\hline \multicolumn{1}{c}{ Variable } & Significance value \\
\hline Parental economic status & 0.20 \\
\hline $\begin{array}{l}\text { Mathematical learning } \\
\text { outcomes }\end{array}$ & 0.14 \\
\hline
\end{tabular}

From Table 1, the significance value of the economic status variable of parents is $0.2>0.05$ then $\mathrm{H}_{0}$ is accepted. Thus, the economic status of parents influences learning outcomes significantly. Then, the normality test is carried out with the results listed in Table 2.

Table 2. Normality Test Results for fifth-grade students of MI Islamiyah Karangpakel

Variable Significance value

\section{The parental economic status of}

learning outcomes in mathematics

0.26

Normality test results show higher values than 0.005 ; thus, it can be concluded that the conditions are normal and average. The next stage is a simple regression test, as shown in Table 3.

Table 3. Data on the results of linear regression tests

Variable
$\begin{aligned} & \text { The economic status of parents } \\ & \text { learning towards mathematics } \\ & \text { learning outcomes }\end{aligned}$
From the analysis of the linearity test, if the calculation is greater
0.05 , then it is declared as linear. From Table 3, the significance
of the economic status variables of parents on mathematics learning


outcomes stated the value of $0.265>0.05$ then $\mathrm{H}_{0}$ was accepted. It is obtained that simple regression test data of $R^{2}$ value is 0.414 , which means that there is an influence of parents' socioeconomic status on mathematics learning outcomes of fifth-grade students at MI Islamiyah Karangpakel by $41.4 \%$ while other variables or factors influence the rest.

Table 4. Data on UTS Mathematics score for the fifth grade of MI Islamiyah Karangpakel students

\begin{tabular}{clc}
\hline No. & \multicolumn{1}{c}{ Name } & Score \\
\hline 1 & Aislamia Rahmawidita & 92 \\
\hline 2 & Ari Bagus Wibowo & 55 \\
\hline 3 & Cahya Ayu Anisa & 61 \\
\hline 4 & Dafa Akmal Praditya & 50 \\
\hline 5 & Daniss Fahma Shania & 52 \\
\hline 6 & Devita Nurhasanah & 86 \\
\hline 7 & Dinar Happy Nastity & 40 \\
\hline 8 & Farra Nur Azalina & 55 \\
\hline 9 & Mariyam Urfat & 60 \\
\hline 10 & Muhammad Fannany & 40 \\
\hline 11 & Muhammad Hanan Zulfan & 54 \\
\hline 12 & Nafis Rayhan Al-Hammar & 75 \\
\hline 13 & Nayla Niswah Maulida & 84 \\
\hline 14 & Pratama Fajar Wibowo & 63 \\
\hline 15 & Raissya Rahma Jirhanita & 50 \\
\hline 16 & Rakka Albar Fahrulloh & 55 \\
\hline 17 & Sandrinayla Huwaida Rifai & 42 \\
\hline 18 & Silvi Eka Septina Ningrum & 80 \\
\hline 19 & Silvina Bening Herningtias & 70 \\
\hline 20 & Zayda Munayasari & 88 \\
\hline Total & 1252 \\
\hline Average & 62.6 \\
\hline Ba & on data analysis, it was known that & \\
\hline
\end{tabular}

Based on data analysis, it was known that the average score of mathematics the fifth-grade students was 62.6, and there was an influence 
between parents' socioeconomic status on the learning outcomes of grade V students in MI Islamiyah Karangpakel. Based on a simple regression analysis, it could be viewed that the socioeconomic status influences $41.4 \%$. So, socioeconomic status could affect the learning outcomes of the fifth grade of MI Islamiyah Karangpakel.

The results of this study revealed that the average parents' socioeconomic status of fifth grade MI Islamiyah Karangpakel students is low social status. It could be seen from the results of the questionnaire analysis of the socioeconomic status, so the average student mathematics learning outcomes are low. It could be elucidated that the socioeconomic status of parents influences the mathematics learning outcomes of fifthgrade students of MI Islamiyah Karangpakel. This result was in line with Sudarsana (2018) that student learning outcomes, which have poor economic levels of parents experience the obstacles, whereas student learning outcomes of capable economic levels do not experience obstacles (Nagel \& Lemel, 2019).

Furthermore, based on the results of the study of Tisar Adi Nugraho (2017: 198), children with weak socioeconomic status have lower learning readiness than friends from the middle to upper economics. However, the socioeconomic status of parents was not the only determinant of the good and bad of mathematics learning outcomes. Nevertheless, it had an impact on the learning process of students in achieving learning outcomes. Further, weak socioeconomic status was not only a determining factor in student learning outcomes. The activeness of 


\section{Mudarrisa: Jurnal Kajian Pendidikan Islam, Vol. 11, No. 2, 2019}

parents in supporting children's achievement in learning also had a role that is also essential than the efforts made by parents such as involving and encouraging children to take extracurricular activities at school or outside school (Martorell et al., 2016: 113; McGrath \& Van Bergen, 2015: 70).

The economic situation of the family has a great role in the development of children, for example, a family whose economy is sufficient can cause the material environment faced by the family to be wider so that they have broad opportunities to develop his skills. According to Abu Ahmadi (1982: 86), skills can be developed if there is full attention from parents, whereas families with low- economic status are more focused on their work and give less attention and guidance to their children. The more complete the educational needs of the children will also increase the desire of students to learn and children's learning outcomes.

Previous research stated that students, whose parents' socioeconomic status were low, were less familiar with books or school activities (Wening, 2011: 73). The low socioeconomic status of parents can cause low student achievement. Islameto in Badrun (2003: 62) explains that the economic situation of the family has a close relationship with children's learning outcomes. Children's needs had be met, such as food, clothing, health, and facilities learning such as study rooms, desks, chairs, lighting, books, and stationery. It can be fulfilled if parents have a sufficient economy. If a child lives in a deprived family, then the needs of the child are not met so that their health and learning processes will be disrupted. Besides that, 
the psychology of children who have a lower economy tends to have a lack of confidence because the conditions are not the same as other children.

\section{CONCLUSION}

Based on data analysis and discussion of research results, it could be concluded that there is an influence between parents' socioeconomic status on mathematics learning outcomes of the fifth-grade students at MI Islamiyah Karangpakel in the academic year of 2019/2020. This result is consistent with the results of a simple regression analysis that obtained a score of 0.414 or the influence of parents' socioeconomic status on the mathematics learning outcomes of the fifth-grade students in Islamiyah Karangpakel by $41.4 \%$ while other variables or factors influenced the rest. In accordance with the data analysis and discussion of research results, it suggested that the results of these studies can help improve the results of mathematics learning in schools. The results of this study can be followed up by the Principal as a consideration in taking steps to improve student learning outcomes, especially in mathematics. For teachers is to utilize teaching materials well, such as books or engaging learning media and teachers can create an effective and efficient learning atmosphere. While for future research, researchers are expected to research more about the factors that affect learning outcomes, especially mathematics. There are other factors such as physical factors (physiology), physical and psychological maturity factors, cultural factors, physical environmental factors, or spiritual environment, and safety that have not been studied. 


\section{REFERENCES}

Fathoni, A.H \& Masykur, M. (2007). Mathematical Intelegensi. Yogyakarta; Ar-Ruzz Media.

Adina, A., \& Colomeischi, T. (2015). The Students `Emotional Life and Their Attitude toward Mathematics Learning. Procedia - Social and Behavioral Sciences, 180(November 2014), 744-750. Retrieved from http://dx.doi.org/10.1016/j.sbspro.2015.02.192.

Ahmadi, Abu. (1982). Sosiologi Pendidikan. Surabaya: PT Bina Ilmu.

Amir, Almira. (2014). Pembelajaran Matematika SD dengan Menggunakan Media Manipulatif, Forum Paedagogik, 6, 1.

Anni, Chatarina Tri, dkk. (2006). Psikologi Belajar. Semarang: UPT MKK UNNES

Avalos, B. (2011). Teacher professional development in Teaching and Teacher Education over ten years. Teaching and Teacher Education, 27(1), $10-20$.

Dalyono, M. (2010). Psikologi Pendidikan. Jakarta: Rineka Cipta.

Hamalik, Oemar. (2009). Kurikulum dan Pembelajaran. Jakarta: PT Bumi Aksara..

Haryanto, Didi. (2015). Filsafat Matematika. Bandung: Alfabeta..

Humaisi, M. Syafiq. (2012). Pengantar Ilmu Pengetahuan Sosial. Ponorogo: STAIN Po Press,.

Ijul, Badrul. (2015). Deskripsi Faktor Sosial Ekonomi Orang Tua dengan Prestasi Belajar Matematika Siswa SMA Negeri 2 Kusambi 
Kabupaten Muna Barat, Jurnal Penelitian Pendidikan Matematika, $3,3$.

Kurniawan, Deni. (2014). Pembelajaran Terpadu tematik.Bandung: Alfabeta,.

Lestari, Indah. (2013). Pengaruh Waktu Belajar dan Minat Belajar terhadap Hasil Belajar Matematika, Jurnal Ilmiah Pendidikan MIPA, 3, 3-5.

Martorell, P., Miller, T., Santibañez, L., \& Augustine, C. H. (2016). Can incentives for parents and students change educational inputs? Experimental evidence from summer school. Economics of Education $\quad$ Review, $\quad$ 50, 113-126. https://doi.org/10.1016/j.econedurev.2015.12.003

McGrath, K. F., \& Van Bergen, P. (2015). Who, when, why and to what end? Students at risk of negative student-teacher relationships and their outcomes, Educational Research Review, Vol. 14, Elsevier Ltd.

Mudzakir, Ahmad \& Sutrisno, J. (1997). Psikologi Pendidikan. Bandung: CV Pustaka Setia.

Muslich, Masur. (2010). Penilaian Berbasis Kelas dan Kompetensi. Bandung: Refika Aditama.

Nasution. (2010). Sosiologi Pendidikan. Jakarta: Bumi Aksara.

Nagel, I., \& Lemel, Y. (2019). Poetics The effects of parents' lifestyle on their children's status attainment and lifestyle in the Netherlands. $\quad$ Poetics, 101357. https://doi.org/10.1016/j.poetic.2019.03.002. 
Noor, M. Arifin. (1997). Ilmu Sosial Dasar. Bandung: CV Pustaka Setia.

Nugroho, Tisar Adi. (2017). Pengaruh Gaya Belajar, Motivasi Belajar, dan Kondisi Ekonomi Orang Tua pada Hasil Belajar, Jurnal Pendidikan, 6,1, 15-26.

Nursalam. (2016). Diagnostik Kesulitan Belajar Matematika: Studi pada Siswa SD/MI di Kota Makassar. Lentera Pendidikan,19.

Observasi dilakukan pada 11 Januari 2019, pukul 09.00 di MI Islamiyah Karangpakel.

Patmi, Wening Rahayu. (2011). Analisis Intensitas Pendidikan oleh Orang Tua dalam Kegiatan Belajar Anak, Status Sosial Ekonomi Orang Tua terhadap Motivasi Belajar dan Prestasi Belajar Siswa, Jurnal Pendidikan dan Pembelajaran, 18, 1.

Sudarsana. (2018). Implikasi Kondisi Ekonomi Orang Tua Terhadap Motivasi dan Hasil Belajar Siswa. Jurnal Pendidikan, 4, $34-48$.

Soejadi. R. (1999). Kiat Pendidikan Matematika di Indonesia, Jakarta: Drektorat Jendral Pendidikan Tinggi.

Sugiono. (2006). Metode Penelitian Pendidikan Pendekatan Kuantitatif, Kualitatif, R E D. Bandung: Alfabeta.

Sukmadinata, Nana Syaodih. (2005). Landasan Psikologi Proses Pendidikan. Bandung: PT Remaja Rosdakarya.

Sulistyorini. (2009). Evaluasi Pembelajaran. Yogyakarta: Teras.

Susanto, Ahmad. (2013). Teori Belajar dan Pembelajaran di Sekolah Dasar. Jakarta: Prenadamedia Group. 
Mudarrisa: Jurnal Kajian Pendidikan Islam, Vol. 11, No. 2, 2019

Sudjana, Nana. (2005). Penilaian Hasil Proses Belajar mengajar. Bandung: Remaja Rosdakarya.

Syahrozi, Ahmad. (2017). Pengaruh Motivasi dan Status Sosial Orang Tua Siswa terhadap Hasil Belajar Siswa di MIN 2 Batu, Thesis, UIN Malik Ibrahim Malang.

Tirtarahardja, Umar. (1998). Pengantar Pendidikan. Jakarta: Rineka Cipta.

Triwiyanto, Teguh. (2015). Pengantar Pendidikan. Jakarta: PT Bumi Aksara.

Muhammad, Thobari \& Mustafa, Arif. (2003). Belajar dan Pembelajaran Pengembangan Wacana dan Praktik Pembelajaran dalam Pengembangan Nasioanal. Yogyakarta: Ar Ruzz Media. 